Curr Opin Anaesthesiol. 2018 February ; 31(1): 55-60. doi:10.1097/ACO.0000000000000549.

\title{
Vitamin C in Sepsis
}

Sven-Olaf Kuhn, MD¹, Konrad Meissner, MD¹, Lena M. Mayes, MD², and Karsten Bartels, $\mathrm{MD}, \mathrm{MS}^{2,{ }^{*}}$

${ }^{1}$ Klinik für Anästhesiologie, Universitätsmedizin Greifswald, Greifswald, Germany

${ }^{2}$ Department of Anesthesiology, University of Colorado Denver, U.S.A

\begin{abstract}
Purpose of review-This narrative review summarizes recent insights into the role of vitamin C in sepsis.

Recent findings-Septic shock remains a major source of morbidity and mortality in critically ill patients. While many nutritional supplements have previously been tested unsuccessfully, vitamins are still being explored as a therapeutic option in septic patients. In particular, vitamin Ccontaining regimens as adjunctive therapy in sepsis have received much attention.
\end{abstract}

Summary-In vitro evidence supports a critical role for vitamin $\mathrm{C}$ in cellular mechanisms relevant to the pathophysiology of sepsis. However, whether this justifies therapeutic use of vitamin $\mathrm{C}$ in septic patients remains uncertain.

\section{Keywords}

sepsis; resuscitation; supplements; vitamin c; ascorbic acid

\section{Introduction}

Sepsis and severe sepsis remain a life-threatening condition and are among the leading causes of death in critically ill patients in non-coronary intensive care units in Western countries. More than 750,000 new cases are diagnosed in the United States per year [1-3].

Despite significant advances in diagnostic and therapeutic capabilities, mortality from sepsis remains high - more than 6 million deaths per year worldwide are attributed to sepsis [4]. Due to different definitions, the reported incidences and mortality of sepsis, severe sepsis, and septic shock remain highly variable and are probably underestimated $[5,6]$. In a retrospective, observational study in patients with severe sepsis from 171 ICUs in Australia and New Zealand, Kaukonen et al. reported a decrease in sepsis mortality from 35\% in 2000 to $18,4 \%$ in 2012 [7]. Yet, in Germany sepsis increased by an average of $5.7 \%$ between 2007

\footnotetext{
*Corresponding Author: Karsten Bartels, M.D., M.S. Assistant Professor, Department of Anesthesiology, University of Colorado Denver, U.S.A. karsten.bartels@ ucdenver.edu, 12401 E. 17th Avenue, Leprino Office Building, 7th Floor, MS B-113, Aurora, CO 80045, U.S.A., Phone: 720-848-6752, Fax: 720-848-7375.

Disclosure

Vitamin C in sepsis is not FDA-labeled for the use under discussion and the product is still investigational for this purpose.

Conflict of Interest

None
} 
and 2013 and in-hospital incidence was 335/100,000 persons per year in 2013 [73]. Here, the mortality rate remained high with $43.6 \%$ for severe sepsis and $58.8 \%$ for septic shock. Of note, a study from Sweden depicted the incidence of sepsis with organ dysfunction to 780/100 000,[8] again higher than what was reported for Australia and New Zealand.

Several therapeutic approaches of promising medical interventions in sepsis failed to improve the condition, or even caused harm [9-12]. Yet, advances in supportive care have led to a reduced case-fatality rate in the past years (e.g. implementation of 3- and 6-hour sepsis 'bundles' by the Surviving Sepsis Campaign and lung-protective ventilation increased awareness and compliance with guidelines) $[13,14]$. However, for the treatment of sepsis and in particular septic shock, anti-infective agents, source control, and maintenance of hemodynamic stability through fluid administration and vasopressors remain the cornerstones of current sepsis therapy.

In sepsis pathophysiology, a dysregulated inflammatory response as a result of a massive release of cytokines and tissue injury embodies one of the pathophysiological origins of endothelial damage $[15,16]$. The relationship between oxidative stress and NF- $\kappa \mathrm{B}$ activation in vivo has been known for over two decades [17]. Oxidative stress, a mediator of the systemic inflammatory response syndrome, is elevated in sepsis. Tissue hypoxia, mitochondrial dysfunction, and depletion of adenosine triphosphate directly affect the microcirculation, contributing to the typical symptoms such as hypotension, cardiomyopathy, and multi-organ dysfunction. Since the beginning of the last century, it is known that in critically ill patients, protective antioxidants, and vitamin c levels in particular, are low $[18,19]$. As oxidative stress is elevated and the consumption of vitamin $\mathrm{C}$ as well as thiamine is increased in sepsis, antioxidant therapy has been suggested as a potential therapeutic approach. Recent studies focusing on vitamin c (ascorbic acid), thiamine and hydrocortisone have resurrected the debate on administration of vitamins in sepsis [20-23].

\section{Pathophysiology of Sepsis}

The new definition characterizes sepsis as life-threatening organ dysfunction caused by a dysregulated host response to infection and septic shock "as a subset of sepsis in which underlying circulatory and cellular metabolism abnormalities are profound enough to substantially increase mortality" [24]. Despite the new definition, sepsis includes a complex host response, which is not fully understood $[13,14,25]$. In sepsis, significant changes in glycocalyx structure, vascular integrity and vasotonus result in capillary leakage, microvascular thrombosis, systemic hypotension and tissue hypo-perfusion, with subsequent multi-organ dysfunction. Glycocalyx disruption is a result of the liberation of several mediator substances including TNFa, oxidized lipoproteins, lipopolysaccharide, and thrombin. Furthermore, an overwhelming production of reactive nitrogen species (RNS) and reactive oxygen species (ROS) in microvascular endothelial cells, and microvascular dysfunction are responsible for glycocalyx shedding, damage of the cellular membranes, and inter-cellular junctions [16,26-28]. This leads to a catecholamine-refractive vasodilation, endothelial barrier dysfunction, and disseminated intravascular coagulation. 


\section{Current therapy of Sepsis}

Septic patients respond differently to a variety of agents, e.g. bacteria, toxins, and products released from damaged tissues. Therefore, fundamental treatment strategies include intravenous fluid replacement, timely antibiotic therapy, and surgical source control, and have been well known for decades. However, several strategies targeting modulation of systemic inflammation failed [12]. Fluid resuscitation using crystalloids, vasopressor therapy, and ventilation are integral to supportive care of severe sepsis and septic shock patients and are administered using a "do no harm" approach [29-32]. Recent studies suggest that fluid resuscitation is most effective within the first 24 to 48 hours of septic shock onset [33]. The first line vasopressor for the therapy of septic shock is norepinephrine [31]. Vasopressin has been found not to be superior to norepinephrine [34]. Yet, as a secondary agent, vasopressin is commonly used to increase peripheral vascular tone [35,36]. The Surviving Sepsis Campaign Guidelines grade the use of hydrocortisone as a weak recommendation in septic shock unresponsive to fluid resuscitation and vasopressor therapy [37]. In addition, established principles of lung-protective ventilation using low tidal volumes and appropriate levels of PEEP, as well as current ARDS treatment are also recommended in septic patients [31]. While intensive glucose control, based on one single center randomized controlled trial [38], had become widespread, a larger multi-center randomized trial found that a glucose target from $82-108 \mathrm{mg} / \mathrm{dL}$ resulted in higher mortality than a more conservative goal of $180 \mathrm{mg} / \mathrm{dL}$ or less [39]. Hence, a target glucose levels of $180 \mathrm{mg} / \mathrm{dL}$ or less are now recommended [31]. Of note, antioxidant supplementation is not part of current sepsis therapy recommendations.

\section{Vitamin C - History}

Since vitamin C (ascorbic acid) was first identified in the 1920s, it has been recommended and applied for the treatment of many diseases, most often without evidence from randomized controlled trials. Indeed, one of its strongest and most controversial proponents was Linus Pauling, Ph.D. (1901-1994), the winner of two Nobel prizes: chemistry and peace. Subsequently though, proposed beneficial effects of vitamin $\mathrm{C}$ to prevent the common cold [40] or to treat cancer [41] were all refuted. Indeed, caution in the use of vitamin C concurrently with anti-neoplastic drugs may be advised, as vitamin $\mathrm{C}$ can reduce their therapeutic efficacy [42]. While the tale of vitamin $C$ is not over, the prevention of scurvy remains the only proven clinical benefit of vitamin $\mathrm{C}$ administration, even though investigated in only twelve sailors [43].

\section{Vitamin C - Proposed Effects}

Antioxidants as an adjuvant therapy in critically ill patients have been described for many decades, mainly as immune nutrition to restore deficits in severe illness. It is widely accepted that the organism requires a complex interacting mixture of endogenous and exogenous antioxidants to protect itself from ROS and RNS. Because humans and some animals like guinea pigs are incapable of synthesizing their own vitamin $\mathrm{C}$ in the liver, they depend on exogenous sources. In healthy organisms, this is sufficient to replenish the demand of vitamin C. In critically ill patients, vitamin C is markedly decreased [18,44]. 
Therefore, the rationale for parenterally administering vitamin $\mathrm{C}$ is to supplement an enhanced metabolic turnover of vitamin $\mathrm{C}$ in severe sepsis and septic shock [45].

Hypotension refractory to catecholamines is a hallmark of septic shock. Apart from fluid resuscitation, it is routinely managed by administration of vasopressors (norepinephrine, vasopressin). Vitamin $C$ increases endogenous synthesis of norepinephrine and vasopressin as a cofactor of dopamine $\beta$-hydroxylase and tyrosine hydroxylase in the synthesis of norepinephrine $[20,46]$. Furthermore, parenteral administration of vitamin $\mathrm{C}$ may improve micro-vascular function in septic patients [47]. The detailed effects of vitamin $\mathrm{C}$, however are complex [48]. Its contribution to endothelial cell proliferation and apoptosis, smooth muscle-mediated vasodilation, and endothelial barrier permeability render vitamin $\mathrm{C}$ an important agent in the treatment of pathophysiological changes in septic shock. Moreover, vitamin $\mathrm{C}$ has bacteriostatic activity [43].

\section{Pre-Clinical Studies on Vitamin C}

It is known from in-vitro studies, that ascorbic acid binds to the a-adrenergic receptor, enhancing its activation by epinephrine. May et al. summarized the beneficial role for vitamin $\mathrm{C}$ in endothelial growth, survival, and ability to maintain vascular responsiveness and integrity [49]. Using a human umbilical endothelial cell line, Mo et al. showed that vitamin C may prevent inflammatory (TNF-alpha)-induced increases in intercellular adhesion molecule-1 (ICAM-1) [50]. There is also some evidence that corticosteroids increase cellular vitamin $\mathrm{C}$ uptake, and that vitamin $\mathrm{C}$ may restore glucocorticoid receptor function [51,52], but in vivo data are lacking. In several animal models of endotoxemia, ARDS, and reperfusion injury, supplementation of antioxidants could substantially reduced metabolic alterations. Experimental data in an animal sepsis model demonstrated that vitamin $\mathrm{C}$ diminishes pro-inflammatory and pro-coagulant changes that induce lung vascular injury [53]. Parenterally administered vitamin $\mathrm{C}$ infusion preserved lung barrier function in a murine sepsis model [54]. In yet another animal study in septic rats, Bark et al. investigated the hypothesis that vitamin $\mathrm{C}$ decreases plasma volume loss in sepsis. Admittedly, they did not find either significant differences in plasma volume or physiological parameters, but a significantly larger urine production in the single bolus dose group ( $200 \mathrm{mg} / \mathrm{kg}$ ), compared to the control group [55]. ROS-generated vascular damage in sepsis may be attenuated by vitamin $\mathrm{C}$ through prevention of increased microvascular permeability, edema formation, and tissue injury seen in a rodent burn model. In thermally injured rats, the generation of early edema was reduced by application of high dose vitamin C [56]. In a sheep burn model, a substantial reduction of early fluid requirements was observed with vitamin C [57]. In summary, there is experimental data for potentially beneficial effects of vitamin $\mathrm{C}$ when applied to experimental models of increased vascular permeability (Figure 1)

\section{Clinical Studies of Vitamin C in Sepsis}

Sepsis is associated with enormous stress to the organism [58]. In animals exposed to stress, an increased endogenous synthesis of ascorbate was found as a compensatory mechanism to maintain the homeostasis $[44,59]$. However, for critically ill patients, neither do we know an optimal vitamin C plasma concentration nor is it known whether supernormal plasma 
concentrations are more beneficial $[60,61]$. However, a number of studies demonstrated that parenteral administration of vitamin $\mathrm{C}$ is more effective to increase plasma levels and reduce multi-organ failure.

Currently there are no large randomized controlled trials for vitamin $\mathrm{C}$ in sepsis and septic shock. In a recent, phase I trial in 24 medical ICU patients with severe sepsis, high dose administration of vitamin $\mathrm{C}$ reduced the extent of multiple organ failure and attenuated circulating injury biomarker levels [19]. In a cohort of 595 critically ill surgical patients Nathens et al. examined the effect of vitamin $\mathrm{E}$ and $\mathrm{C}$ in preventing the development of pulmonary morbidity and organ failure. They found a reduced incidence of organ failure and shortened ICU length of stay after early enteral supplementation of vitamins [62]. In a double-blinded randomized clinical trial, 28 adult surgical patients with septic shock had a significantly decreased vasopressor requirement and a faster weaning of vasopressors. In addition to these findings, 28-day mortality was significantly lower in the ascorbic acid, compared to the placebo group [63].

Burns are associated with enormous inflammation, followed by endothelial leakage. In a prospective RCT in 37 severely burned patients, the administration of high-dose vitamin C during the first 24 hours of injury significantly reduced fluid requirement, and was associated with a higher urine output and less wound edema [64,65].

New information on the role of vitamin $\mathrm{C}$ in septic shock is derived from a retrospective before-and-after clinical study in 94 patients [23]. Patients receiving vitamin $\mathrm{C}$ in combination with thiamine and hydrocortisone had a significantly reduced mortality. However, design features such as small study size, before-and-after study design, singecenter, lack of blinding, and the presence of three simultaneous interventions limit generalizability of these findings. While potentially useful for generating future hypotheses, they are insufficient to introduce changes into clinical practice.

It has been shown in healthy volunteers that high-level ascorbic acid plasma concentrations could only be achieved by intravenous administration, not by enteral intake [66]. In most studies, doses as high as 1 to $2 \mathrm{~g}$ q8h of ascorbate were administered intravenously. In burned patients, a very high dose of ascorbate $(1,584 \mathrm{mg} / \mathrm{kg} / \mathrm{day})$ was well tolerated, and associated with a significant reduction in fluid intake, pulmonary dysfunction, and tissue edema [67]. In the recent study mentioned above, Marik et al. administered $1500 \mathrm{mg}$ vitamin C IV q6, thiamine $200 \mathrm{mg} \mathrm{q} 12$ for 4 days, or until ICU discharge, and $50 \mathrm{mg}$ hydrocortisone IV q6 (optional $50 \mathrm{mg}$ bolus, followed by a 24-hour continuous infusion of $200 \mathrm{mg}$ ) for 4 days [23].

\section{Adverse Effects of High Dose Vitamin C}

High-dose vitamin $\mathrm{C}$ has been administered by complementary and alternate medicine practitioners for many years [68]. Apart from renal impairment and glucose-6-phosphate dehydrogenase deficiency, several potentially toxic effects were reported. A calcium oxalate nephropathy as a result of metabolization into oxalic acid is one known complication of high-dose administration of vitamin C. Indeed, this effect is dose-dependent, but no adverse 
clinical impact was observed in healthy volunteers [69]. Of note, pro-oxidative mechanisms mediated by vitamin $\mathrm{C}$ are discussed, along with anti-oxidant effects, in human volunteers [70,71]. Taken together, prior human studies employing pharmacologic ascorbic acid administration reported no adverse events. However, if vitamin $\mathrm{C}$ were to be administered in high doses clinically, point-of-care blood glucose measurements may become inaccurate, since the molecular structures of vitamin $\mathrm{C}$ and glucose are somewhat similar - such measurements should therefore be approached with caution [72].

\section{Conclusion}

In critically ill patients, vitamin $\mathrm{C}$ deficiency is frequently observed. After almost one century of in vitro-experiments and animal models, there is an abundance of plausible data for the protective effects of vitamin $\mathrm{C}$ against oxidative-stress-mediated cell damage and organ dysfunction in sepsis and septic shock, respectively. Only with parenteral high-dose administration, vitamin $\mathrm{C}$ deficiency can be restored efficiently. The lack of randomized controlled trials and the uncertainty regarding optimal dose, timing and possible adverse effects impeded the clinical acceptance, and preclude a recommendation for vitamin $\mathrm{C}$ in the clinical care of septic patients. Thus, further research is needed to investigate the benefit of vitamin $\mathrm{C}$ in sepsis and septic shock.

\section{Acknowledgments}

None

Financial Support

Karsten Bartels is supported by the National Institutes of Health (NIH), Award Number K23DA040923. The content of this report is solely the responsibility of the authors and does not necessarily represent the official views of the NIH. The NIH had no involvement in study design, collection, analysis, interpretation of data, writing of the report, or the decision to submit the article for publication.

\section{References}

1. Martin GS, Mannino DM, Eaton S, Moss M. The epidemiology of sepsis in the United States from 1979 through 2000. N Engl J Med. 2003; 348:1546-54. [PubMed: 12700374]

2. Dombrovskiy VY, Martin AA, Sunderram J, Paz HL. Facing the challenge: decreasing case fatality rates in severe sepsis despite increasing hospitalizations. Critical Care Medicine. 2005; 33:2555-62. [PubMed: 16276180]

3. Gaieski DF, Edwards JM, Kallan MJ, Carr BG. Benchmarking the incidence and mortality of severe sepsis in the United States. Critical Care Medicine. 2013; 41:1167-74. [PubMed: 23442987]

4. Fleischmann C, Scherag A, Adhikari NKJ, Hartog CS, Tsaganos T, Schlattmann P, et al. Assessment of Global Incidence and Mortality of Hospital-treated Sepsis. Current Estimates and Limitations. Am J Respir Crit Care Med. 2016; 193:259-72. [PubMed: 26414292]

5. Lindenauer PK, Lagu T, Shieh M-S, Pekow PS, Rothberg MB. Association of diagnostic coding with trends in hospitalizations and mortality of patients with pneumonia, 2003-2009. JAMA. 2012; 307:1405-13. [PubMed: 22474204]

6. Rhee C, Kadri SS, Danner RL, Suffredini AF, Massaro AF, Kitch BT, et al. Diagnosing sepsis is subjective and highly variable: a survey of intensivists using case vignettes. Crit Care. 2016; 20:89. [PubMed: 27048508]

7. Kaukonen K-M, Bailey M, Suzuki S, Pilcher D, Bellomo R. Mortality related to severe sepsis and septic shock among critically ill patients in Australia and New Zealand, 2000-2012. JAMA. 2014; 311:1308-16. [PubMed: 24638143] 
8. Mellhammar L, Wullt S, Lindberg Å, Lanbeck P, Christensson B, Linder A. Sepsis Incidence: A Population-Based Study. Open Forum Infect Dis. 2016; 3:ofw207. [PubMed: 27942538]

9. Sprung CL, Annane D, Keh D, Moreno R, Singer M, Freivogel K, et al. Hydrocortisone therapy for patients with septic shock. N Engl J Med. 2008; 358:111-24. [PubMed: 18184957]

10. Ranieri VM, Thompson BT, Barie PS, Dhainaut J-F, Douglas IS, Finfer S, et al. Drotrecogin alfa (activated) in adults with septic shock. N Engl J Med. 2012; 366:2055-64. [PubMed: 22616830]

11. Heyland D, Muscedere J, Wischmeyer PE, Cook D, Jones G, Albert M, et al. A randomized trial of glutamine and antioxidants in critically ill patients. N Engl J Med. 2013; 368:1489-97. [PubMed: 23594003]

12. Marshall JC. Why have clinical trials in sepsis failed? Trends Mol Med. 2014; 20:195-203. [PubMed: 24581450]

13. Dellinger RP, Levy MM, Carlet JM, Bion J, Parker MM, Jaeschke R, et al. Surviving Sepsis Campaign: International guidelines for management of severe sepsis and septic shock: 2008. Critical Care Medicine. 2008; 36:296-327. [PubMed: 18158437]

14. Dellinger RP, Levy MM, Rhodes A, Annane D, Gerlach H, Opal SM, et al. Surviving Sepsis Campaign: International Guidelines for Management of Severe Sepsis and Septic Shock, 2012. Intensive Care Med. 2013; 39:165-228. [PubMed: 23361625]

15. Biesalski HK, McGregor GP. Antioxidant therapy in critical care-is the microcirculation the primary target? Critical Care Medicine. 2007; 35:S577-83. [PubMed: 17713412]

16**. Ince C, Mayeux PR, Nguyen T, Gomez H, Kellum JA, Ospina-Tascón GA, et al. THE ENDOTHELIUM IN SEPSIS. Shock (Augusta, Ga). 2016; 45:259-70. A very worth reading paper about the pathophysiology of endothelial cell lining of the vasculature and its clinical significance for organ function.

17. Blackwell TS, Blackwell TR, Holden EP, Christman BW, Christman JW. In vivo antioxidant treatment suppresses nuclear factor-kappa B activation and neutrophilic lung inflammation. $\mathrm{J}$ Immunol. 1996; 157:1630-7. [PubMed: 8759749]

18. Gabbe E. Bestimmung von Vitamin C im Blutserum. Klin Wochenschr. 1934; 13:1389-92.

19. Fowler AA, Syed AA, Knowlson S, Sculthorpe R, Farthing D, DeWilde C, et al. Phase I safety trial of intravenous ascorbic acid in patients with severe sepsis. J Transl Med. 2014; 12:32. [PubMed: 24484547]

20. Carr AC, Shaw GM, Fowler AA, Natarajan R. Ascorbate-dependent vasopressor synthesis: a rationale for vitamin $\mathrm{C}$ administration in severe sepsis and septic shock? Crit Care. 2015; 19:418. [PubMed: 26612352]

21. Marik P, Bellomo R. A rational approach to fluid therapy in sepsis. British Journal of Anaesthesia. 2016; 116:339-49. [PubMed: 26507493]

22. Donnino MW, Andersen LW, Chase M, Berg KM, Tidswell M, Giberson T, et al. Randomized, Double-Blind, Placebo-Controlled Trial of Thiamine as a Metabolic Resuscitator in Septic Shock: A Pilot Study. Critical Care Medicine. 2016; 44:360-7. [PubMed: 26771781]

23**. Marik PE, Khangoora V, Rivera R, Hooper MH, Catravas J. Hydrocortisone, Vitamin C, and Thiamine for the Treatment of Severe Sepsis and Septic Shock: A Retrospective Before-After Study. Chest. 2017; 151:1229-38. The author presents astonishing results of a simple combination therapy of 3 well known and cheap agents for patients with septic shock. It should be a catalyzer of large randomized clinical trials. [PubMed: 27940189]

24. Singer M, Deutschman CS, Seymour CW, Shankar-Hari M, Annane D, Bauer M, et al. The Third International Consensus Definitions for Sepsis and Septic Shock (Sepsis-3). JAMA. 2016; 315:801-10. [PubMed: 26903338]

25. Seymour CW, Liu VX, Iwashyna TJ, Brunkhorst FM, Rea TD, Scherag A, et al. Assessment of Clinical Criteria for Sepsis: For the Third International Consensus Definitions for Sepsis and Septic Shock (Sepsis-3). JAMA. 2016; 315:762-74. [PubMed: 26903335]

26. Rubio-Gayosso I, Platts SH, Duling BR. Reactive oxygen species mediate modification of glycocalyx during ischemia-reperfusion injury. Am J Physiol Heart Circ Physiol. 2006; 290:H2247-56. [PubMed: 16399871]

27. Burke-Gaffney A, Evans TW. Lest we forget the endothelial glycocalyx in sepsis. Crit Care. 2012; 16:121. [PubMed: 22494667] 
28. De Backer D, Orbegozo Cortes D, Donadello K, Vincent J-L. Pathophysiology of microcirculatory dysfunction and the pathogenesis of septic shock. Virulence. 2014; 5:73-9. [PubMed: 24067428]

29. Bartels K, Thiele RH, Gan TJ. Rational fluid management in today's ICU practice. Crit Care. 2013; 17(Suppl 1):S6. [PubMed: 23514431]

30. Dellinger RP, Schorr CA, Levy MM. A users' guide to the 2016 Surviving Sepsis Guidelines. Intensive Care Med. 2017:1-5.

31*. Rhodes A, Evans LE, Alhazzani W, Levy MM, Antonelli M, Ferrer R, et al. Surviving Sepsis Campaign: International Guidelines for Management of Sepsis and Septic Shock: 2016. Critical Care Medicine. 2017; 45:486-552. State of the art in sepsis management. [PubMed: 28098591]

32. Howell MD, Davis AM. Management of Sepsis and Septic Shock. JAMA. 2017; 317:847-8. [PubMed: 28114603]

33. Sakr Y, Rubatto Birri PN, Kotfis K, Nanchal R, Shah B, Kluge S, et al. Higher Fluid Balance Increases the Risk of Death From Sepsis: Results From a Large International Audit. Critical Care Medicine. 2017; 45:386-94. [PubMed: 27922878]

34. Russell JA, Walley KR, Singer J, Gordon AC, Hébert PC, Cooper DJ, et al. Vasopressin versus norepinephrine infusion in patients with septic shock. N Engl J Med. 2008; 358:877-87. [PubMed: 18305265]

35. Saad AF, Maybauer MO. The role of vasopressin and the vasopressin type V1a receptor agonist selepressin in septic shock. Journal of Critical Care. 2017; 40:41-5. [PubMed: 28319910]

36. Suzuki T, Suzuki Y, Okuda J, Kurazumi T, Suhara T, Ueda T, et al. Sepsis-induced cardiac dysfunction and $\beta$-adrenergic blockade therapy for sepsis. 2017:1-10.

37. Rhodes A, Evans LE, Alhazzani W, Levy MM, Antonelli M, Ferrer R, et al. Surviving Sepsis Campaign. Critical Care Medicine. 2017; 45:486-552. [PubMed: 28098591]

38. van den Berghe G, Wouters P, Weekers F, Verwaest C, Bruyninckx F, Schetz M, et al. Intensive insulin therapy in critically ill patients. N Engl J Med. 2001; 345:1359-67. [PubMed: 11794168]

39. NICE-SUGAR Study Investigators. Finfer S, Chittock DR, Su SY-S, Blair D, Foster D, et al. Intensive versus conventional glucose control in critically ill patients. N Engl J Med. 2009; 360:1283-97. [PubMed: 19318384]

40. Pitt HA, Costrini AM. Vitamin C prophylaxis in marine recruits. JAMA. 1979; 241:908-11. [PubMed: 368370]

41. Creagan ET, Moertel CG, O'Fallon JR, Schutt AJ, O'Connell MJ, Rubin J, et al. Failure of highdose vitamin $\mathrm{C}$ (ascorbic acid) therapy to benefit patients with advanced cancer. A controlled trial. N Engl J Med. 1979; 301:687-90. [PubMed: 384241]

42. Heaney ML, Gardner JR, Karasavvas N, Golde DW, Scheinberg DA, Smith EA, et al. Vitamin C antagonizes the cytotoxic effects of antineoplastic drugs. Cancer Res. 2008; 68:8031-8. [PubMed: 18829561]

43. Mandl J, Szarka A, Bánhegyi G. Vitamin C: update on physiology and pharmacology. British Journal of Pharmacology. 2009; 157:1097-110. [PubMed: 19508394]

44. Nakano K, Suzuki S. Stress-induced change in tissue levels of ascorbic acid and histamine in rats. J Nutr. 1984; 114:1602-8. [PubMed: 6206215]

45. Borrelli E, Roux-Lombard P, Grau GE, Girardin E, Ricou B, Dayer J, et al. Plasma concentrations of cytokines, their soluble receptors, and antioxidant vitamins can predict the development of multiple organ failure in patients at risk. Critical Care Medicine. 1996; 24:392-7. [PubMed: 8625625]

46. Galley HF, Howdle PD, Walker BE, Webster NR. The Effects of Intravenous Antioxidants in Patients With Septic Shock. Free Radic Biol Med. 1997; 23:768-74. [PubMed: 9296454]

47. Wilson JX. Mechanism of action of vitamin C in sepsis: ascorbate modulates redox signaling in endothelium. Biofactors. 2009; 35:5-13. [PubMed: 19319840]

48. Oudemans-van Straaten HM, Spoelstra-de Man AM, de Waard MC. Vitamin C revisited. Crit Care. 2014; 18:460. [PubMed: 25185110]

49. May JM, Harrison FE. Role of vitamin C in the function of the vascular endothelium. Antioxid Redox Signal. 2013; 19:2068-83. [PubMed: 23581713] 
50. Mo S-J, Son E-W, Rhee D-K, Pyo S. Modulation of TNF-alpha-induced ICAM-1 expression, NO and $\mathrm{H} 2 \mathrm{O} 2$ production by alginate, allicin and ascorbic acid in human endothelial cells. Arch Pharm Res. 2003; 26:244-51. [PubMed: 12723939]

51. Okamoto K, Tanaka H, Makino Y, Makino I. Restoration of the glucocorticoid receptor function by the phosphodiester compound of vitamins $\mathrm{C}$ and E, EPC-K1 (L-ascorbic acid 2-[3,4dihydro-2,5,7,8-tetramethyl-2-(4,8,12-trimethyltridecyl)-2H-1-benzopyran-6-yl hydrogen phosphate] potassium salt), via a redox-dependent mechanism. Biochem Pharmacol. 1998; 56:7986. [PubMed: 9698091]

52. Fujita I, Hirano J, Itoh N, Nakanishi T, Tanaka K. Dexamethasone induces sodium-dependant vitamin C transporter in a mouse osteoblastic cell line MC3T3-E1. Br J Nutr. 2001; 86:145-9. [PubMed: 11502226]

53. Fisher BJ, Seropian IM, Kraskauskas D, Thakkar JN, Voelkel NF, Fowler AA, et al. Ascorbic acid attenuates lipopolysaccharide-induced acute lung injury. Critical Care Medicine. 2011; 39:145460. [PubMed: 21358394]

54. Fisher BJ, Kraskauskas D, Martin EJ, Farkas D, Wegelin JA, Brophy D, et al. Mechanisms of attenuation of abdominal sepsis induced acute lung injury by ascorbic acid. Am J Physiol Lung Cell Mol Physiol. 2012; 303:L20-32. [PubMed: 22523283]

55. Bark BP, Grände P-O. The effect of vitamin C on plasma volume in the early stage of sepsis in the rat. Intensive Care Med Exp. 2014; 2:11. [PubMed: 26266908]

56. Tanaka H, Lund T, Wiig H, Reed RK, Yukioka T, Matsuda H, et al. High dose vitamin C counteracts the negative interstitial fluid hydrostatic pressure and early edema generation in thermally injured rats. Burns. 1999; 25:569-74. [PubMed: 10563680]

57. Dubick MA, Williams C, Elgjo GI, Kramer GC. High-dose vitamin C infusion reduces fluid requirements in the resuscitation of burn-injured sheep. Shock (Augusta, Ga). 2005; 24:139-44.

58. Macdonald J, Galley HF, Webster NR. Oxidative stress and gene expression in sepsis. British Journal of Anaesthesia. 2003; 90:221-32. [PubMed: 12538380]

59. LAHIRI S, LLOYD BB. The effect of stress and corticotrophin on the concentrations of vitamin C in blood and tissues of the rat. Biochem J. 1962; 84:478-83. [PubMed: 14461597]

60. Wilson JX. Evaluation of Vitamin C for Adjuvant Sepsis Therapy. Antioxid Redox Signal. 2013; 19:2129-40. [PubMed: 23682970]

61. Berger MM, Oudemans-van Straaten HM. Vitamin C supplementation in the critically ill patient. Curr Opin Clin Nutr Metab Care. 2015; 18:193-201. [PubMed: 25635594]

62. Nathens AB, Neff MJ, Jurkovich GJ, Klotz P, Farver K, Ruzinski JT, et al. Randomized, prospective trial of antioxidant supplementation in critically ill surgical patients. Ann Surg. 2002; 236:814-22. [PubMed: 12454520]

63. Zabet MH, Mohammadi M, Ramezani M, Khalili H. Effect of high-dose Ascorbic acid on vasopressor's requirement in septic shock. J Res Pharm Pract. 2016; 5:94-100. [PubMed: 27162802]

64. Tanaka H, Matsuda T, Miyagantani Y, Yukioka T, Matsuda H, Shimazaki S. Reduction of resuscitation fluid volumes in severely burned patients using ascorbic acid administration: a randomized, prospective study. Arch Surg. 2000; 135:326-31. [PubMed: 10722036]

65. Kahn SA, Beers RJ, Lentz CW. Resuscitation after severe burn injury using high-dose ascorbic acid: a retrospective review. J Burn Care Res. 2011; 32:110-7. [PubMed: 21131846]

66. Padayatty SJ, Sun H, Wang Y, Riordan HD, Hewitt SM, Katz A, et al. Vitamin C pharmacokinetics: implications for oral and intravenous use. Ann Intern Med. 2004; 140:533-7. [PubMed: 15068981]

67. Tanaka H. Reduction of Resuscitation Fluid Volumes in Severely Burned Patients Using Ascorbic Acid Administration. Arch Surg. 2000; 135:326-31. [PubMed: 10722036]

68. Padayatty SJ, Sun AY, Chen Q, Espey MG, Drisko J, Levine M. Vitamin C: intravenous use by complementary and alternative medicine practitioners and adverse effects. PLoS ONE. 2010; 5:e11414. [PubMed: 20628650]

69. Levine M, Conry-Cantilena C, Wang Y, Welch RW, Washko PW, Dhariwal KR, et al. Vitamin C pharmacokinetics in healthy volunteers: evidence for a recommended dietary allowance. Proc Natl Acad Sci USA. 1996; 93:3704-9. [PubMed: 8623000] 
70. Podmore ID, Griffiths HR, Herbert KE, Mistry N, Mistry P, Lunec J. Vitamin C exhibits prooxidant properties. Nature. 1998; 392:559-9. [PubMed: 9560150]

71. Guidarelli A, De Sanctis R, Cellini B, Fiorani M, Dachà M, Cantoni O. Intracellular ascorbic acid enhances the DNA single-strand breakage and toxicity induced by peroxynitrite in U937 cells. Biochem J. 2001; 356:509-13. [PubMed: 11368779]

72. Sartor Z, Kesey J, Dissanaike S. The effects of intravenous vitamin C on point-of-care glucose monitoring. J Burn Care Res. 2015; 36:50-6. [PubMed: 25127026]

73. Fleischmann C, Thomas-Rueddel DO, Hartmann M, et al. Hospital Incidence and Mortality Rates of Sepsis. Dtsch Arztebl Int. 2016 Mar 11; 113(10):159-66. [PubMed: 27010950] 


\section{Key points}

- Oxidative stress is a mediator of systemic inflammatory response syndrome and is elevated in sepsis.

- Vitamin C deficiency is associated with increased morbidity in critically ill patients.

- Ascorbic acid is a co-factor for the synthesis of dopamine, norepinephrine and serotonin. Vitamin C plays an important role in limiting oxidative stress and maintaining endothelial integrity.

- Careful monitoring for adverse effects if vitamin $\mathrm{C}$ administration is paramount for future clinical studies.

- $\quad$ Randomized controlled trials are needed prior to routine use of Vitamin C in the therapy of sepsis. 


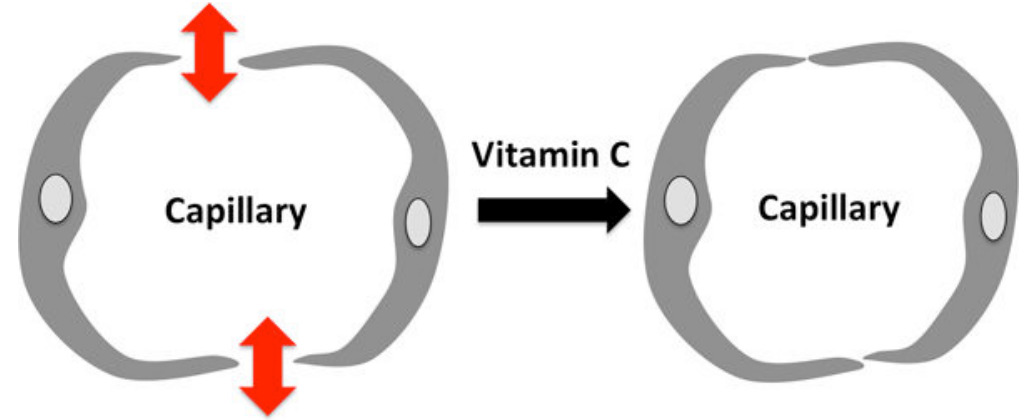

Tissue edema

Figure 1.

In animal models of increased vascular permeability, vitamin $C$ restores endothelial integrity and capillary function. 